\title{
Light and Color in the Open Air: Introduction by the Feature Editor
}

James A. Lock

Cleveland State University, j.lock@csuohio.edu

Craig F. Bohren

Follow this and additional works at: https://engagedscholarship.csuohio.edu/sciphysics_facpub

Part of the Physics Commons

How does access to this work benefit you? Let us know!

\section{Publisher's Statement}

This paper was published in Applied Optics and is made available as an electronic reprint with the permission of OSA. The paper can be found at the following URL on the OSA website: http://www.opticsinfobase.org/ao/abstract.cfm?URI=ao-30-24-3381. Systematic or multiple reproduction or distribution to multiple locations via electronic or other means is prohibited and is subject to penalties under law.

\section{Original Citation}

Lock, James A. "Light and Color in the Open Air: Introduction by the Feature Editor." Applied Optics 30 (1991): 3381-3381.

\section{Repository Citation}

Lock, James A. and Bohren, Craig F., "Light and Color in the Open Air: Introduction by the Feature Editor" (1991). Physics Faculty Publications. 118.

https://engagedscholarship.csuohio.edu/sciphysics_facpub/118

This Editorial is brought to you for free and open access by the Physics Department at EngagedScholarship@CSU. It has been accepted for inclusion in Physics Faculty Publications by an authorized administrator of EngagedScholarship@CSU. For more information, please contact library.es@csuohio.edu. 


\section{Light and color in the open air: introduction by the feature editor}

James A. Lock

A number of years ago Marcel Minnaert wrote a book ${ }^{1}$ that attempted to express the joy that he experienced in observing and understanding optical phenomena in the natural world around him. ${ }^{2,3}$ This collection of papers, which takes its name from Minnaert's book, is an attempt on the part of the authors similarly to express the joy that they experience in observing and understanding nature. This collection grew out of the talks presented at the topical meeting Light and Color in the Open Air, held in Washington, D.C., on 11-13 July, 1990.4 In this technological age, the analysis of naked eye optical phenomena is a largely neglected field of research. But it is also a rich and challenging field, as evidenced by the enthusiasm of the 48 attendees from 6 countries at the topical meeting and from the high quality and wide variety of the 30 talks presented there. It was the point of view of the attendees and presenters alike that not only does the analysis of naked eye optical phenomena represent good physics but also observing and enjoying the beauty of the natural world enriches our lives.

It is quite fitting that this collection of papers appear in Applied Optics, because these papers represent the application of optics in the large sense-to a wide range of fields of human endeavor including physics, meteorology, biology, psychology, and art. It has been said that the true expression of science is not to be found in the performing of experiments or in the carrying out of calculations. Rather, it is to be found in the understanding of nature that one derives from those experiments and calculations. The authors sincerely hope that they have communicated this understanding to the readership of Applied Optics.

\section{References}

1. M. Minnaert, Light and Color in the Open Air (Dover, New York, 1954).

2. M. Minnaert, "Unusual or neglected optical phenomena in the landscape," J. Opt. Soc. Am. 58, 297-303 (1968).

3. W. C. Livingston, "Marcel Minnaert and optics in nature," Appl. Opt. 19, 648-649 (1980).

4. Three similar collections of papers associated with topical meetings on atmospheric optics have been published. These are J. Opt. Soc. Am. 69, 1051-1198 (1979); 73, 1622-1664 (1983); J. Opt. Soc. Am. A 4, 558-620 (1987).

\footnotetext{
James A. Lock is with the Department of Physics, Cleveland State University, Cleveland OH 44115

Received 29 May 1991.

0003/6935/91/243381-01\$05.00/0

(C) 1991 Optical Society of America.
} 